JURNAL WARTA FARMASI
Volume 8 | Nomor 2 | Oktober | 2019
ISSN: 2089-712X

\title{
Uji Daya Hambat Ekstrak Etanol Bintang Laut Bertanduk (Protoreaster nodosus) Terhadap Pertumbuhan Bakteri Staphylococcus aureus
}

\section{The Tests Of Ethanol Extract Of A Signed Sea Star (Protoreaster nodosus) On The Growth Of Bacteria Staphylococcus aureus}

\author{
Randa Wulaisfan*, Selfyana Austin Tee, Febriyanti Mala \\ Politeknik Bina Husada Kendari \\ Jl. Sorumba No. 17 Kendari - Sulawesi Tenggara 93117, Tlp./Fax : 0401-390193 \\ Email : randa.laugidemara@gmail.com, selfyjanet@gmail.com
}

\begin{abstract}
INTISARI
Bintang laut bertanduk merupakan salah satu biota laut yang digunakan sebagai obat tradisional. Salah satunya adalah pengobatan infeksi. Infeksi merupakan salah satu penyebab penyakit yang sering terjadi di daerah yang beriklim tropis khususnya Indonesia. Salah satu infeksi yang sering terjadi adalah infeksi pada kulit yang disebabkan oleh bakteri Staphylococcus aureus. Penelitian ini bertujuan untuk mengetahui apakah ekstrak etanol bintang laut bertanduk dapat menghambat pertumbuhan bakteri Staphylococcus aureus. Jenis penelitian yang digunakan dalam penelitian ini adalah penelitian eksperimental yang terdiri atas lima perlakuan dan tiga kali pengulangan dengan menggunakan metode pengujian paper disk. Sampel uji yang diteliti adalah bintang laut bertanduk (Protoreaster nodosus) yang dilarutkan dalam DMSO 10\% hingga didapatkan varian konsentrasi 5\%, 10\%, dan 15\% kemudian dilakukan uji daya hambat terhadap bakteri Staphylococcus aureus. Hasil penelitian menunjukkan bahwa ekstrak bintang laut bertanduk menghambat pertumbuhan bakteri Staphylococcus aureus masing-masing konsentrasi 5\%, 10\% dan $15 \%$ yakni $5,99 \mathrm{~mm}, 6,69 \mathrm{~mm}$ dan $7,64 \mathrm{~mm}$. Berdasarkan hasil tersebut dapat disimpulkan bahwa ekstrak etanol bintang laut bertanduk(Protoreaster nodosus) dapat menghambat pertumbuhan bakteri Staphylococcus aureus secara signifikan.
\end{abstract}

Kata kunci : Zona Hambat, Bintang Laut Bertanduk, Staphylococcus aureus.

\begin{abstract}
Horned starfish are one of the marine biota used as traditional medicine. One of them is the treatment of infections. Infection is one of the causes of diseases that often occur in the tropics, especially Indonesia. One infection that often occurs is an infection of the skin caused by Staphylococcus aureus. This study aims to determine whether the horned starfish ethanol extract can inhibit the growth of Staphylococcus aureus bacteria.

This type of research used in this study is an experimental study consisting of five treatments and three repetitions using a diskette testing method. The test sample studied was a horned starfish (Protoreasternodosus) dissolved in DMSO 10\% to 5\%, 10\%, and 15\% of the variant of concentration was obtained then the inhibitory test was performed on Staphylococcus aureus bacteria. The results showed that the horned starfish extract inhibited the growth of Staphylococcus aureus, each
\end{abstract}


concentrations of $5 \%, 10 \%$ and $15 \%$ respectively $5.99 \mathrm{~mm}, 6.69 \mathrm{~mm}$ and $7.64 \mathrm{~mm}$. Based on these results it can be concluded that the ethanol extract of the horned starfish (Protoreasternodosus) can significantly inhibit the growth of Staphylococcus aureus bacteria.

Keywords: Inhibited zone, Horn Star, Staphylococcus aureus.

\section{Pendahuluan}

Infeksi merupakan salah satu penyebab penyakit yang sering terjadi di daerah yang beriklim tropis khususnya Indonesia. Bakteri patogen adalah salah satu penyebab infeksi pada manusia. Salah satu infeksi yang sering terjadi adalah infeksi pada kulit yang disebabkan oleh bakteri Staphylococcus aureus (Siregar \& Pringgenies, 2012).

Penyakit kulit dapat menyerang siapa saja dan dapat menyerang pada bagian tubuh manapun. Penyakit kulit salah satu penyakit yang sering dijumpai pada negara beriklim tropis seperti Indonesia. Data Profil Kesehatan Indonesia 2010 menunjukkan bahwa penyakit kulit menjadi peringkat ketiga dari sepuluh penyakit terbanyak pada pasien rawat jalan dirumah sakit seIndonesia (Kemenkes, 2010). Kejadian penyakit kulit di Indonesia masih tergolong tinggi dan menjadi permasalahan yang cukup berarti. Hal tersebut karena kurangnya kesadaran dan ketidak pedulian masyarakat terhadap lingkungan sekitar yang menyebabkan penularan penyakit kulit sangat cepat. Berbagai penyakit kulit dapat disebabkan oleh beberapa faktor seperti lingkungan dan kebiasaan sehari-hari yang buruk, perubahan iklim, virus, bakteri, alergi, daya tahan tubuh dan lain-lain (Pardiansyah, 2015).

Staphylococcus aureus ditemukan pada saluran pernapasan atas, muka, tangan, rambut, dan vagina. Infeksi bakteri ini dapat menimbulkan penyakit dengan tanda-tanda yang khas, yaitu peradangan, nekrosis, tampak sebagai jerawat, infeksi folikel rambut, dan pembentukan abses. Diantara organ yang saling diserang oleh bakteri Staphylococcus aureusa dalah kulit yang mengalami luka dan dapat menyebar ke orang lain yang juga mengalami luka (Razak \& Revilla, 2013).

Dalam pengobatan penyakit infeksi karena mikroba, antibiotika mempunyai peranan penting, dimana antibiotic diharapkan mampu mengeliminasi mikroba penyebab infeksi. Akan tetapi kebanyakan obat antibiotika menyebabkan resisten terhadap mikroba. Sehingga untuk menghindari masalah ini, para ilmuan lebih tertarik untuk mengembangkan antibiotik baru dari organisme uniseluler, jamur, alga, dan tumbuhan tingkat tinggi. 
Uji Daya Hambat Ekstrak Etanol Bintang Laut Bertanduk (Protoreaster nodosus) Terhadap Pertumbuhan

Bakteri Staphylococcus aureus

Randa Wulaisfan, dkk, Hal. 31 - 42

Indonesia memiliki sumber daya alam laut yang besar baik ditinjau dari kuantitas maupun keanekaragaman hasilnya. Meskipun organisme laut adalah sumber zat obat yang berpotensi besar, sedikit sekali obat dari bahan alam yang berasal dari laut. Kebanyakan obat Kita justru berasal dari tanaman atau mikroorganisme darat. Zat obat yang terdapat di dalam organisme laut mempunyai struktur kimia beranekaragam. Struktur molekulnya pun tidak sama dengan yang ditemukan pada tanaman darat. Senyawa bioaktif bintang laut sangat menarik untuk diteliti terutama berkaitan dengan sifat karakteristik kimia maupun biokimianya serta pemanfaatannya untuk bidang pangan dan kesehatan.

Kandungan kimia yang terdapat pada ekstrak bintang laut yaitu alkaloida, triterpenoida, saponin dan flavonoida (Agustina, 2012 dan Juariah 2014). Selain pada bintang laut bertanduk, pada bintang laut jenis yang lain yaitu bintang laut Culcita sp. terhadap bakteri Staphylococcus aureus dan Salmonella typhi. Penelitian lain mengenai uji daya hambat ekstrak etanol bintang laut bertanduk terhadap pertumbuhan baktri Streptococcus sp. Dan C albicans., memiliki respon hambatan pertumbuhan yang dapat dikategori kuat 32.000 ppm dan terhadap pertumbuhan candida albicans ATCC 10231 bersifat kuat pada konsentrasi 32.000 ppm, 16.000 ppm, 8.000 ppm dan 4000 ppm.

Maserasi digunakan untuk penyarian simplisia yang mengandung zat aktifyang mudah larut dalam cairan penyari, tidak mengandung zat yang mudah mengembang dalam cairan penyari, tidak mengandung benzoin, stirak, dan lain-lain. Cairan penyari yang digunakan dapat berupa air, etanol, air-etanol, atau pelarut lain. Bila cairan penyari digunakan air maka untuk mencegah timbulnya kapang, dapat ditambahkan bahan pengawet, yang diberikan pada awal penyarian. Keuntungan cara penyarian dengan maserasi adalah cara pengerjaan dan peralatan yang digunakan sederhana dan mudah diusahakan. Sedangkan kerugiancara maserasi adalah pengerjaannya lama dan penyariannya kurang sempurna. Maserasi pada umumnya dilakukan dengan cara: 10 bagian simplisia dengan derajat halus yang cocok dimasukkan ke dalam bejana, kemudian dituangi dengan 75 bagian cairan penyari, ditutup dan dibiarkan selama 5 hari terlindung dari cahaya, sambil berulangulang diaduk. Setelah 5 hari sari diserkai, ampas diperas. Ampas ditambah cairan penyari secukupnya diaduk dan 
diserkai,sehingga diperoleh seluruh sari sebanyak 100 bagian. Benjana ditutup, dibiarkan ditempat sejuk, terlindung dari cahaya, selama 2 hari. Kemudian endapan dipisahkan .

\section{Metodologi}

\section{Alat dan Bahan}

Alat yang digunakan dalam penelitian yaitu batang pengaduk, corong pisah, Rotavapor, wadah maserasi (toples). Alat yang di gunakan pada uji daya hambat yaitu Autoclaf (mammer), cawan petri (pirex), erlenmeyer (pirex), gelas kimia (pirex), gelas ukur (pirex), hot plate ( $H$ $H P-I I)$, inkubator (yenaco), jangka sorong, jarum ose, labu ukur, lampu spiritus, micropipet (adjustable), oven (yenaco), pinset, rak tabung, tabung reaksi (pyrex), timbangan analitik, timbangan digital, alat pelubang.

Bahan yang digunakan yaitu Alkohol, Alluminium foil, ,bakteri uji staphylococcus aureus, DMSO $10 \%$ ekstrak bintang laut bertanduk, etanol 96\%, kain flannel, kertas saring, media Mueller Hinton Agar, media Nutrient Agar, , NaCl $0,9 \%$,

\section{Prosedur Penelitian}

\section{Penyiapan sampel}

Disiapkan alat dan bahan yang akan digunakan. Dikumpulkan dan dipilih sampel yang memiliki ukuran sama besar lalu disortasi basah. Dicuci bintang laut dengan air mengalir, dibebas garamkan, dirajang, kemudian ditiriskan. Dikeringkan dengan cara diangin-anginkan.

\section{Pembuatan Ekstrak Bintang Laut}

\section{Bertanduk dengan Metode Maserasi.}

Ditimbang simplisia sebanyak 500 gram. Dimasukkan ke dalam wadah maserasi. Ditambahkan cairan penyari (etanol 96\%) sebanyak $3750 \mathrm{~mL}$ sampai sampel terendam, ditutup disimpan diluar pengaruh cahaya. Dimaserasi selama 3 hari sesekali dilakukan pengadukan. Disaring menggunakan kain flannel. Ampas kemudian diremaserasi sampai hasil filtrat maserasi mendekati warna pelarut etanol $96 \%$ (tersari sempurna). Dipekatkan dengan alat rotary evaporator hingga diperoleh ekstrak kental. kemudian diuapkan dengan alat rotary evaporator.

Pengenceran Ekstrak 5\%, 10\% dan $15 \%$.

Ditimbang $\quad 0,5$ gram untuk konsentrasi 5\%, 1 gram untuk konsentrasi $10 \%$ dan 1,5 gram untuk konsentrasi $15 \%$. Ditambahkan DMSO 10\% hingga $10 \mathrm{~mL}$ untuk masing-masing konsentrasi diaduk hingga homogen lalu dimasukkan kedalam botol dan diberi label. 


\section{Sterilisasi alat dan bahan}

\section{Sterilisasi alat}

Dibersihkan alat dengan sabun dan air kemudian dikeringkan, ditutup mulut tabung reaksi dan erlenmeyer dengan kapas yang telah dilapisi kain kasa, dibungkus tabung reaksi dengan menggunakan kertas HVS, dimasukkan alat yang tidak berskala pada oven pada suhu $180^{\circ} \mathrm{C}$ selama $2 \mathrm{jam}$. Sedangkan alat yang berskala dimasukkan dalam autoclaf pada suhu $121^{\circ} \mathrm{C}$ selama 15 menit dan dikeluarkan alat-alat setelah selesai.

\section{Sterilisasi Media}

Dibungkus media yang telah dibuat dengan kertas HVS, dibuka tutup autoclaf serta aluminiumnya masukkan media kedalam autoclaf lalu tutup rapat. Sambungkan pada stok kontak tunggu hingga mencapai suhu $121^{\circ} \mathrm{C}$ selama 15 menit.

\section{Pembuatan media}

Timbang media MHA sebanyak 5,7 gram lalu masukkan kedalam erlenmeyer kemudian larutkan dengan aquades sebanyak $150 \mathrm{~mL}$, aduk hingga larut dengan menggunakan batang pengaduk, pindahkan diatas penangas air hingga mendidih sambil diaduk kemudian sterilkan dalam autoclaf pada suhu $121^{\circ} \mathrm{C}$ selama 15 menit dinginkan danukur $\mathrm{pH}$ media MHA.

\section{Penyiapan bakteri Staphylococcus} aureus

Ambil satu ose biakan bakteri Staphylococcus aureus menggunakan jarum ose yang telah disterilkan, goreskan pada media mueller hinton agar miring, inkubasi pada suhu $37^{\circ} \mathrm{C}$ selama $24 \mathrm{jam}$, Pembuatan Suspensi Bakteri Uji Ambil sebanyak 1 ose biakan bakteri Staphylococcus aureus yang telah diremajakan dimedia Nutrient Agar, masukkan kedalam tabung reaksi yang telah berisi $9 \mathrm{~mL}$ larutan $\mathrm{NaCl}$ 0,9\%, kocok sampai homogen.

\section{Pembuatan Kontrol Positif}

Timbang kloramfenikon sebanyak 0,1 gram, masukkan kedalam gelas kimia, larutkan dengan aquadest sedikit demi sedikit, masukkan kedalam labu tentukur $10 \mathrm{~mL}$.

\section{Pengujian Diameter Zona Hambat} Fraksi n-heksan Ekstrak Akar Bawang Merah Terhadap Pertumbuhan Bakteri Staphylococcus aureus

Dituangkan media MHA sebanyak 15-20 mL kedalam 3 cawan petri, biarkan hingga memadat (Lapisan 1) kemudian dipipet $3 \mathrm{~mL}$ suspensi bakteri kemudian dimasukkan kedalam media NA. Dituangkan media MHA yang bercampur bakteri sebanyak $15-20 \mathrm{~mL}$ kedalam 3 cawan petri yang berisi lapisan 1, biarkan 
hingga memadat. Diteteskan masingmasing ekstrak etanol bintang laut bertandukkedalam kertas cakram yang berdiameter $6 \mathrm{~mm}$. Dimasukkan 5 lembar kertas cakram kedalam cawan petri yang diatur jaraknya masing-masing didalamnya terdapat ekstrak bintang laut, kontrol negatif (DMSO 10\%) dan kloramfenikol sebagai kontrol positif. Ditempatkan pada permukaan media tepat diatas koloni Staphylococcus aureus kemudian dibiarkan selama 30 menit pada suhu kamar sebelum di inkubasi.. Diinkubasi selama 2 hari pada suhu $37^{\circ} \mathrm{C}$ dan diukur zona hambat yang terbentuk.

\section{Hasil dan Pembahasan}

Penelitian uji daya hambat ekstrak etanol bintang laut bertanduk (Protoreaster nodosus) terhadap pertumbuhan bakteri Staphylococcus aureus bertujuan untuk mengetahui daya hambat antibakteri ekstrak bintang laut bertanduk (Protoreaster nodosus) terhadap pertumbuhan bakteri Staphylococcus aureus.

Sampel yang digunakan pada penelitian ini adalah bintang laut bertanduk (Protoreaster nodosus) yang diambil dari pantai Toronipa Kota Kendari Sulawesi Tenggara. Pada pembuatan simplisia sudah memenuhi syarat good clinical practice (GCP) dan good manufacturing pracrice
(GMP) yaitu sortasi basah, pencucian, pengecilan ukuran, pengerian, sortasi kering, penimbangan dan penyimpanan. Tujuan preparasi sampel adalah untuk memastikan mutu Sampel memenuhi syarat zat aktif dalam pengujian aktivitas antibakteri terhadap pertumbuhan bakteri S. Aureus (Hafizah \& Sulastriana, 2015).

Ekstraksi bintang laut bertanduk yang digunakan menggunakan metode maserasi, Metode maserasi dipilih karena alat yang digunakan sederhana dan dalam prosesnya tanpa mengalami pemanasan sehingga dapat menghindari rusaknya senyawa-senyawa yang bersifat termolabil (Depkes, RI. 1986). Proses maserasi dilakukan selama 3 hari pada temperatur kamar dan terlindung dari cahaya matahari dengan sesekali dilakukan pengadukan. Selanjutnya dilakukan remaserasi yaitu metode ekstraksi yang terjadi penambahan pelarut setelah dilakukan penyaringan maserat pertama dan seterusnya, pelarut kedua (remaserasi) ditambahkan sebanyak penambahan pelarut pertama. Sampel kering bintang laut bertanduk yang digunakan sebanyak 500 gram dengan pelarut etanol 96\% sebanyak $3750 \mathrm{~mL}$. Pelarut etanol $96 \%$ merupakan pelarut yang umum digunakan dan dapat melarutkan senyawa polar maupun nonpolar karena sifatnya yang semi polar 
Uji Daya Hambat Ekstrak Etanol Bintang Laut Bertanduk (Protoreaster nodosus) Terhadap Pertumbuhan Bakteri Staphylococcus aureus Randa Wulaisfan, dkk, Hal. 31 - 42

sehingga di harapkan senyawa metabolit sekunder yang terkandung dalam akar bawang merah dapat tertarik ke dalam pelarut.

Ekstrak cair yang diperoleh kemudian diuapkan hingga kental menggunakan alat rotary evaporator pada suhu $50-70^{\circ} \mathrm{C}$. Suhu rotavapor tidak boleh melebihi titik didih pelarut yang di gunakan, titik didih etanol yaitu $78^{\circ} \mathrm{C}$.

Kontrol positif yang digunakan adalah kloramfenikol karena merupakan antibiotik yang berspektrum luas yang efektif terhadap gram negatif dan gram positif, yang dapat mengatasi infeksi yang disebabkan oleh bakteri $S$. aureus sedangkan untuk kontrol negatif digunakan adalah DMSO 10\%. Pemilihan DMSO 10\%. sebagai kontrol negatif dikarenakan pada saat pembuatan seri konsentrasi ekstrak dapat melarutkan senyawa polar maupun non-polar (Wulaisfan \& Musdalipah, 2018). Metode yang digunakan untuk pengujian ini yaitu metode cakram kertas dengan karena pengujian dikarenakan kertas cakram sering mendukung zat antimikroba dengan kekuatan tertentu dan jumlah zat yang digunakan dapat diatur. Penggunaan media MHA pada pengujian penentuan sensibilitas mikroorganisme adalah hampir seluruh bakteri dapat tumbuh karena media ini bukan media selektif dan media diferensial, kemudian MHA memiliki tingkat inhibitor sulfonamide, trimethoprim, dan tetracycline rendah, selain iitu MHA dapat mendukung pertumbuhan bakteri non-fastidious yang patogen bakteriologi (Siregar \& Pringgenies,2012)

Tabel 1. Hasil perhitungan luas zona hambat fraksi n-heksan ekstrak akar bawang merah (Allium cepa L) terhadap pertumbuhan Staphylococcus aureus

\begin{tabular}{ccccc}
\hline \multirow{2}{*}{ Perlakuan } & \multicolumn{3}{c}{ Luas zona hambat (mm) } & \multirow{2}{*}{$\begin{array}{c}\text { Rata-rata } \\
(\mathrm{mm})\end{array}$} \\
\cline { 2 - 4 } & $\mathrm{I}$ & $\mathrm{II}$ & $\mathrm{III}$ & \\
\hline $5 \%$ & 5,99 & 5,98 & 6,01 & 5,99 \\
$10 \%$ & 6,68 & 6,68 & 6,73 & 6,69 \\
$15 \%$ & 7,61 & 7,61 & 7,70 & 7,64 \\
(+) kloramfenikol & 11,69 & 10,66 & 12,26 & 11,61 \\
(-) DMSO 10\% & 0 & 0 & 0 & 0 \\
\hline
\end{tabular}

Dari Tabel 1. terlihat bahwa ekstrak menghambaat pertumbuhan S. aureus pada etanol bintang laut bertanduk dapat konsentrasi $5 \% \mathrm{~b} / \mathrm{v}$ dengan rata-rata luas 
Uji Daya Hambat Ekstrak Etanol Bintang Laut Bertanduk (Protoreaster nodosus) Terhadap Pertumbuhan

Bakteri Staphylococcus aureus

Randa Wulaisfan, dkk, Hal. 31 - 42

zona hambat yaitu 5,99 $\mathrm{mm}$, konsentrasi $b / v$ yaitu 7,64 mm, konsentrasi .

$10 \% \mathrm{~b} / \mathrm{v}$ yaitu $6,69 \mathrm{~mm}$ dan konsentrasi $15 \%$

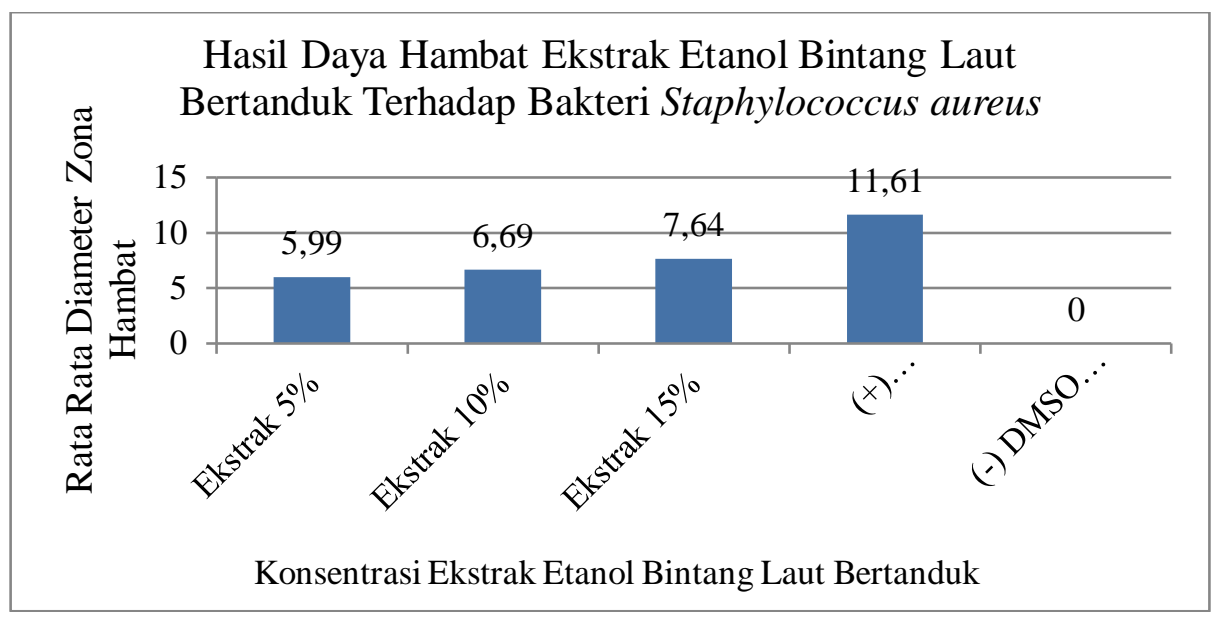

Gambar 1. Diagram hasil perhitungan luas zona hambat Ekstrak Etanol Bintang Laut Bertanduk Terhadap Bakteri Staphylococcus aureus

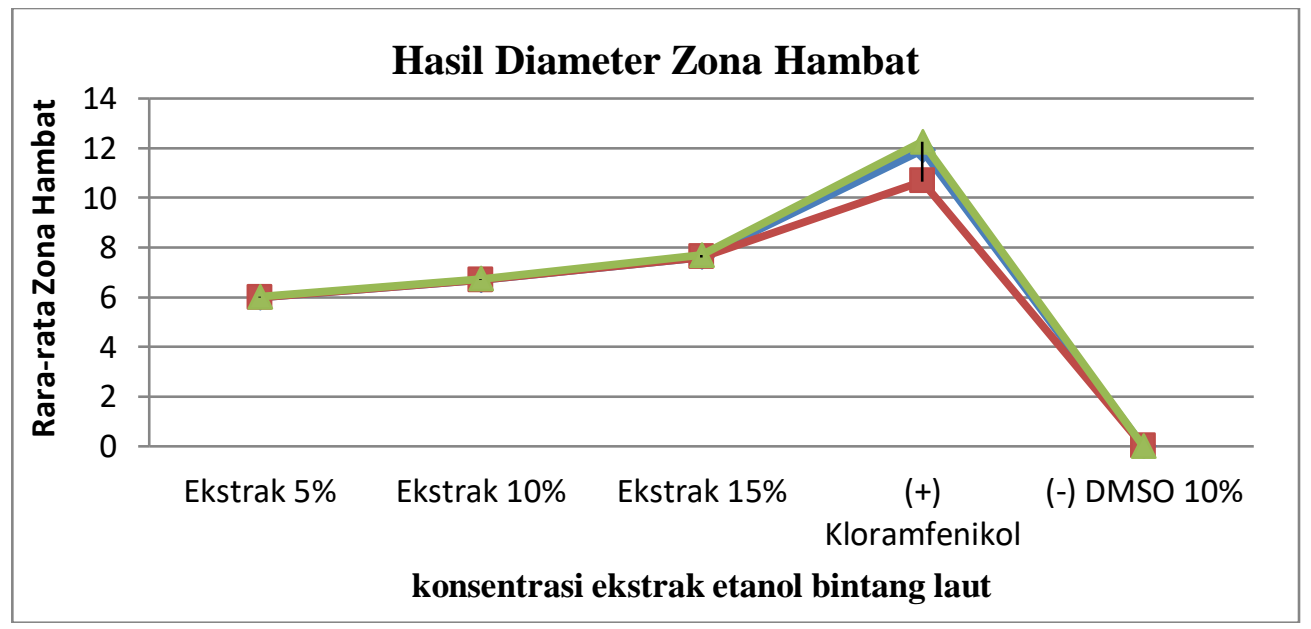

Gambar 2. Grafik hasil perhitungan luas zona hambat Ekstrak Etanol Bintang Laut Bertanduk Terhadap Bakteri Staphylococcus aureus

Menurut Hapsari (2015) efektifitas suatu zat antibakteri diklasifikasikan ada 4 kategori yaitu $<5 \mathrm{~mm}$ adalah kategori lemah, 5-10 $\mathrm{mm}$ adalah kategori sedang, 10-20 mm adalah kategori kuat, dan > 20 mm adalah kategori sangat kuat. Sehingga menurut perhitungan luas zona hambat yang dapat dilihat pada Tabel 1. dengan konsentrasi $5 \% b / v, 10 \% b / v$ dan $15 \% b / v$ masuk dalam kategori sedang. Berdasarkan 
Uji Daya Hambat Ekstrak Etanol Bintang Laut Bertanduk (Protoreaster nodosus) Terhadap Pertumbuhan

Bakteri Staphylococcus aureus Randa Wulaisfan, dkk, Hal. 31 - 42

hasil penelitian uji daya hambat ekstrak etanol bintang laut bertanduk (Protoreaster nodosus) terhadap pertumbuhan bakteri $S$. aureus, mampu menghambat pertumbuhan bakteri $S$. aureus masuk dalam kategori sedang. Hal ini diduga hasil ekstrak yang diperoleh banyak mengandung komponen zat ballast. Zat ballast adalah senyawa pengotor yang terkandung dalam sampel seperti (klorofil, lemak, protein, resin, lilin dan senyawa nonpolar lainnya), yang dapat mengganggu suatu bahan alam dalam menghasilkan aktivitas biologi.

Adanya daya hambat tersebut disebabkan adanya senyawa tanin, saponin dan flavonoid yang terkandung dalam bintang laut bertanduk. Flavonoid menyebabkan terjadinya kerusakan permeabilitas dinding sel bakteri dan menghambat motilitas bakteri. Senyawa flavonoida mengandung gugus hidroksil menyebabkan perubahan komponen organik dan transport nutrisi yang menimbulkan efek toksik terhadap bakteri. Mekanisme kerja tanin sebagai antibakteri adalah menghambat enzim reverse transkriptase dan DNA topoisomerase sehingga sel bakteri tidak terbentuk Senyawa Saponin bekerja sebagai antibakteri dengan cara mengganggu stabilitas dan permeabilitas membran sel bakteri sehingga merusak membran sel dan menyebabkan keluarnya berbagai komponen penting sel bakteri yaitu protein, asam nukleat dan nukleotida (Sugianitri, 2011).

\section{Kesimpulan}

Berdasarkan hasil penelitian yang telah dilakukan mengenai uji daya hambat ekstrak etanol bintang laut bertanduk (Protoreaster nodosus) terhadap pertumbuhan bakteri $S$. aureus dapat diperoleh kesimpulan, ekstrak etanol bintang laut bertanduk (Protoreaster nodosus) pada konsentrasi 5\% b/v, 10\% b/v dan $15 \% b / v$ memiliki respon hambatan pertumbuhan pada kategori sedang.

\section{Ucapan Terima Kasih}

1. Kampus Politeknik Bina Husada Kendari.

2. Dosen-dosen Prodi D-III Farmasi yang telah membantu menyelesaikan artikel penelitian ini.

\section{Daftar Pustaka}

Agustina, D. S. 2012. Aktivitas Antioksidan dan Komponen Bioaktif Ekstrak Bintang Laut Culcita sp. Bogor: Departemen Teknologi Hasil Perairan Fakultas Perikanan dan IlmuKelautan Institut Pertanian Bogor. 
Depkes, RI. 1986. Sediaan Galenik. Jakarta.

Gama,dkk. (2017). Perbandingan Efektifitas Antibakteri Ekstrak Bintang Laut Culcita Sp. Terhadap Pertumbuhan Bakteri Staphylococcus Aureus Dan Salmonella typhi. Lampung: Universitas Lampung Fakuta Kedokteran.

Hapsari, Endah. 2015. Uji Antibakteri Ekstrak Herba Meniran (Phyllanthus niruri) terhadap Pertumbuhan Bakteri Bacillus cereus dan Escherichia coli.Skripsi. Pendidikan Biologi. Universitas Sanata Dharma.Yogyakarta.

Hafizah \& Sulastriana (2015). Uji daya hambat ekstrak etanol bintang laut bertanduk (Protoreaster nodosus) terhadap bakteri Strepococcus $S p$ dan $C$ Albicans Fakultas Kedokteran Universitas Halu Oleo Kendari, Indonesia: UHO.

Kandhasamy M, Arunachalam, Thatheyus AJ. Drynaria quercifolia(L.) J.Sm: A potential resource forantibacterial activity. AfricanJournal of Microbiology Research, 2008.

Kementerian Kesehatan Indonesia, 2010. Profil Kesehatan Indonesia Tahun 2009.Jakarta: Kementerian Kesehatan RI.

Pardiansyah, R., 2015. Association Between Personal Protective Equipment Withthe Irritant Contact Dermatitis inScavengers.Faculty of Medicine,Lampung University.

Razak, A., Djamal, A., \& Revilla, G. (2013). Artikel Penelitian Uji Daya
Hambat Air Perasan Buah Jeruk Nipis (Citrus Aurantifolia S.) Terhadap Pertumbuhan Bakteri Staphylococcus Aureus Secara In Vitro, 2(1), 5-8. Retrieved From Http://Jurnal.Fk.Unand.Ac.Id.

Rusli, dkk. 2016. Jamur endosiombion si bintang laut asterias forbesi sebagai alternative sebagai antibakteri baru pada bakteri penyebab infeksi saluran pencernaan.

Siregar, A. F., Sabdono, A., \& Pringgenies, D. (2012). Potensi Antibakteri Ekstrak Rumput Laut Terhadap Bakteri Penyakit Kulit Pseudomonas Aeruginosa, Staphylococcus Epidermidis, Dan Micrococcus Luteus Dari Laboratorium Balai Kesehatan Jawa. Http://EjournalS1.Undip.Ac.Id/Index.Php/Jmr Potensi, 1(2), 152-160.

Wulaisfan, R., \& Musdalipah. (2018). Aktivitas ekstrak kulit bawang merah (allium ascalonicum 1.) Terhadap pertumbuhan bakteri Streptococcus mutans. Jurnal Ilmiah Farmasyifa, 1(2), 126-132. 